\title{
Pengaruh Penggunaan Gawai terhadap Prestasi Belajar Matematika Siswa pada Masa Pandemi COVID-19
}

\author{
Alfiah Amir
}

Alfiah Amir. (2021). Pengaruh penggunaan gawai terhadap prestasi belajar matematika siswa pada masa pandemi covid-19. Kognitif: Jurnal Riset HOTS Pendidikan Matematika, 1(2), $115 \quad-\quad 123$. https://doi.org/10.51574//kognitif.v1i2.102

To link to this article : https://doi.org/10.51574/kognitif.v1i2.102

Opened Access Article

Published Online on 1 Desember 2021

兵 Submit your paper to this journal 


\title{
Pengaruh Penggunaan Gawai Terhadap Prestasi Belajar Matematika Siswa Pada Masa Pandemi COVID-19
}

\author{
Alfiah Amir ${ }^{1}$ \\ ${ }^{1}$ Program Magister Pendidikan Matematika, Fakultas Keguruan dan Ilmu Pendidikan, Universitas \\ Cokroaminoto Palopo
}

\begin{tabular}{l} 
Article Info \\
Article history: \\
Received Aug 28, 2021 \\
Accepted Sept 29, 2021 \\
Published Online Dec 1, 2021 \\
\hline
\end{tabular}

Keywords:

Gawai

Prestasi Belajar Matematika

Covid-19

\begin{abstract}
Pada masa pandemi seperti saat ini kebutuhan akan komunikasi dan informasi menjadi hal yang paling penting bagi semua kalangan masyarakat, terutama siswa yang melakukan pembelajaran daring,tetapi terkadang pada masa ini pemanfaatan gawai bagi siswa tidak di barengi dengan kontrol diri siswa dimana terlihat bahwa siswa lebih banyak menggunakan gawainya untuk bermain game,mendownload game, mendengarkan musik, dan sebagainya jika pemanfaatan gawai tidak dalam pembelajaran maka hal tersebut berpengaruh terhadap prestasi belajar siswa. Penelitian ini bertujuan untuk mengetahui gamabaran: (1) penggunaan gawai bagi siswa di Kecamatan wara pada masa pandemic covid-19 (2) gambaran prestasi belajar matematika siswa SD (3) pengaruh penggunaan gawai terhadap prestasi belajar matematika siswa SD.Penelitian ini adalah penelitian expost facto, jenis desain penelitian ini adalah pendekatan kuantitatif instrumen penelitian ini menggunakan angket dan tes matematika untuk mengukur prestasi belajar matematika siswa. Hasil penelitian ini ditemukan bahwa: (1) hasil penggunaan gawai terhadap prestasi belajar Jumah siswa yang masuk pada kategori sangat tinggi sebanyak 43 orang, yang berkategori tinggi sebanyak 42 orang, sedangkan yang masuk pada kategori cukup sebanyak 1 orang dan tidak terdapat siswa pada kategori kurang (2) hasil prestasi belajar matematika Perhitungan berdasarkan kriteria ketuntasan minimal (KKM) diperoleh 51 siswa tuntas dan 35 dinyatakan tidak tuntas dari seluruh siswa
\end{abstract}

This is an open access under the $\underline{C C-B Y-S A}$ licence

All rights reserved

\section{Corresponding Author:}

Alfiah Amir,

Magister Pendidikan Matematika,

Fakultas Keguruan dan Ilmu Pendidikan

Universitas Cokroaminoto Palopo

Email: fhiakhanza@gmail.com 


\section{Pendahuluan}

Di masa pandemi seperti saat ini kebutuhan akan komunikasi dan informasi menjadi hal yang paling penting bagi semua kalangan masyarakat, terutama siswa yang melakukan pembelajaran daring. Pembelajaran daring menggunakan gawai menjadikan siswa senantiasa bersentuhan dengan teknologi yang memungkinkan mengakses berbagai macam layanan (fitur) yang ditawarkan dari penyedia jasa layanan dari produsen ponsel cerdas itu sendiri dan berbagai provider pendukung. Semenjak merebaknya pandemi Covid-19 di semua belahahan dunia, maka secara tidak langsung sistem pendidikan mulai mencari inovasi dalam proses pendidikan dan pembelajaran. Selanjutnya, pada April 2020, Kemendikbud merekomendasikan agar semua kegiatan di lembaga pendidikan dihindari dan semua materi dikirim ke rumah masing-masing. Pembelajaran di satuan pendidikan mengubah bentuk umum kegiatan dengan mengikuti kegiatan pembelajaran jarak jauh dan mengikut pada kebijakan sosial yang diinstruksikan oleh pemerintah selama masa pandemi covid-19,

Proses belajar "daring" merupakan satu pilihan pilihan dalam kondisi pencegahan penyebaran covid 19 memberi warna khusus pada masa perjuangan melawan virus ini. Pada metode pembelajaran daring sarana yang paling dibutuhkan oleh siswa untuk mengakses pembelajaran yang diberikan oleh guru adalah gawai. Gawai atau smartphone adalah contoh perubahan komunikasi elektronik yang berkembang pesat dan sangat berpengaruh dikalangan masyarakat tidak terkecuali siswa yang masih duduk dibangku sekolah dasar. Gawai tidak hanya sebagai alat komunikasi, tetapi juga gaya hidup, penampilan, dan tren. Pada mulanya, gawai cuma dipakai oleh mereka yang sangat membutuhkan, seperti pekerja kantoran, pengusaha, pegawai negeri, dan guru. Namun, kini gawai tidak hanya dipakai oleh orang-orang penting, tetapi juga oleh murid-murid sekolah. Tidak dapat dipungkiri bahwa anak-anak zaman sekarang lebih sering bermain gawai dari pada belajar dan berinteraksi dengan lingkungan sekitarnya. Hal ini sangat mengkhawatirkan karena masa kanak-kanak adalah masa yang masih labil, rasa ingin tahu mereka sangat besar, dan berdampak pada peningkatan konsumtif anak. Maka dari itu peran orang tua sangat dibutuhkan untuk melakukan pengawasan terhadap anakanak dalam penggunaan perangkat gawai ini. Beberapa kasus yang terkait dengan dampak negatif gawai ini dimulai dari kecanduan internet, game, bahkan pornografi, yang sering menimpa anak-anak.

Afandi (2020) dan Widiawati et al (2014) mengemukakan bahwa prestasi adalah hasil belajar atau perubahan yang melibatkan ilmu pengetahuan, keterampilan, sikap dan pengalaman pribadi dalam berinteraksi dengan lingkungan. Alifzal (2020) Belajar adalah proses aktivitas mental seseorang saat berinteraksi dengan lingkungan untuk menghasilkan perubahan perilaku yang positif, yaitu perubahan baik pengetahuan, sikap maupun pola pikir. Dikatakan hasil yang baik dapat dicapai tergantung pada berhasil tidaknya proses belajar yang telah dilalui siswa. Prestasi yang baik juga dimulai dengan proses belajar yang baik prestasi siswa juga dapat dilihat dari penampilan siswa di dalam kelas. Oleh karena itu, proses pembelajaran harus berhasil supaya siswa mendapatkan predikat yang baik pula. Hidayat \& Junianto (2017), ada dua faktor yang mempengaruhi keberhasilan akademik siswa yaitu : faktor yang berasal dari siswa itu sendiri dan faktor dari luar siswa itu sendiri. Ada tiga faktor dari diri siswa adalah faktor keletihant (jasmani dan mental), faktor fisik (kesehatan, kecacatan) dan faktor psikologis (perhatian, minat, bakat, kedewasaan, motivasi), kemampuan, kemampuan belajar, kecerdasan). Sementara faktor dari luar diri siswa berasal dari individu seperti keluarga, sekolah, dan masyarakat.

Akibatnya, kebiasaan ini membuat siswa merasa bahwa belajar tidak lagi menjadi tujuan utama. Perkembangan gawai dengan fitur yang semakin menarik dan modern juga menjadi daya pikat bagi anak-anak, karena anak-anak cenderung memilih menggunakan gawai 
daripada belajar dan mengerjakan pekerjaan rumah. Keadaan perilaku anak yang telah kecanduan gawai secara langsung dapat menghambat animo belajar dan menyulitkan mereka untuk fokus belajar Yang seiring dengan hasil penelitian yang dikemukakan oleh Istiqomah (2019) menyatakan bahwa anak-anak yang sering menggunakan gawai membuat mereka malas untuk belajar serta lebih menyenangi sesuatu yang instant demi mengatasi masalah mereka. sehingga sangat penting untuk melakukan penelitian dan inkuiri untuk mengetahui seberapa besar Pengaruh Penggunaan Gawai Dan Kontrol Diri Terhadap Prestasi Belajar Matematika Siswa SD Kelas VI di Kecamatan Wara Pada Masa Pandemi Covid-19.

Berdasarkan uraian latar belakang di atas maka penulis bermaksud melakukan penelitian tentang Pengaruh Penggunaan Gawai Terhadap Prestasi Belajar Matematika Siswa SD Kelas VI di Kecamatan Wara Pada Masa Pandemi Covid-19. Permasalahan dari penelitian ini adalah : (1) Bagaimanakah gambaran penggunaan gawai bagi siswa SD kelas VI di Kecamatan Wara pada masa pandemi covid-19? (2). Bagaimanakah gambaran prestasi belajar matematika siswa SD kelas VI di Kecamatan Wara selama menggunakan gawaipada masa pandemi covid-19? (3). Apakah penggunaan gawai berpengaruh terhadap prestasi belajar matematika siswa SD kelas VI di Kecamatan wara pada masa pandemi covid-19?

Penelitian ini bertujuan untuk (1) Untuk mengetahui gambaran penggunaan gawai bagi siswa SD KelasVI di Kecamatan Wara pada masa pandemi covid-19. (2) Untuk mengetahui gambaran presstasi belajar matematika siswa SD kelas VI di Kecamatan Wara dalam penggunaan gawai di masa pandemi covid-19. (3) Untuk mengetahui apakah terdapat pengaruh penggunaan gawai terhadap prestasi belajar matematika siswa SD kelas VI di Kecamatan Wara pada masa pandemi covid-19.

Sesuai dengan tujuan penelitian yang akan dicapai, maka melalui penelitian ini diharapkan dapat memberi manfaat berupa : (1) Hasil penelitian ini diharapkan agar memberikan pedoman kepada guru dalam memahami manfaat dan dampak yang ditimbulkan akibat penggunaan gawai dalam menunjang prestasi belajar siswa (2) Diharapakan penelitian ini dapat memperluas khasanah ilmu pengetahuan yang bermanfaat bagi semua pihak yang ada dalam bidang pendidikan khususnya pendidikan matematika

\section{Metode}

Penelitian ini merupakan penelitian ex-post facto dengan menggunakan pendekatan kuitantatif untuk menemukan ada atau tidaknya pengaruh yang signifikan antara penggunaan gawai terhadap prestasi belajar matematika siswa SD kelas VI selama masa pandemi Covid-19. Peneliti merupakan guru pada SD Negeri 12 Langkanae Kota Palopo Sulawesi Selatan. Penelitian ini dilaksanakan pada bulan April tahun 2021, dan lokasi penelitiannya adalah sekolah dasar yang berada pada wilayah Kecamatan Wara Kota Palopo sebanyak 12 sekolah dasar negeri. Populasi dalam penelitian ini adalah siswa kelas VI sebanyak 636 siswa. Teknik pengumpulan sampel yang digunakan adalah simple random sampling Penentuan jumlah sampel dari penelitian ini diambil dengan memakai rumus yang dikeluarkan oleh Slovin cara pengambilan sampel diambil dari bagian terkecil populasi sehingga ditemukan sampel sebanyak 86 siswa,sampel yang diambil bisa memberikan gambaran yang jelas tentang ada atau tidaknya pengaruh penggunaan gawai terhadap prestasi belajar matematika siswa SD kelas VI di Kecamatan Wara pada masa pandemic covid-19 ini. dapat ditunjukan dengan desain penelitian berikut :

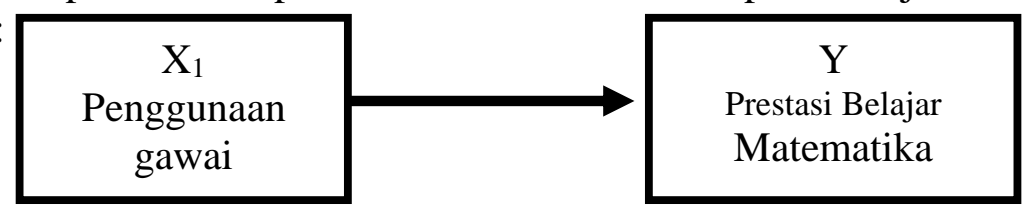

Gambar 1. Desain penelitian 


\section{Hasil Penelitian}

Instrumen yang digunakan pada penelitian ini adalah angket penggunaan gawai, berupa pernyataan positif dan pernyataan negatif yang terdiri dari 30 pernyataan. Sedangkan tes prestasi belajar matematika berupa soal berbentuk pilihan ganda sebanyak 30 butir soal. Penelitian ini dilakukan di masa pandemi Covid-19, Pada masa ini pemerintah mewajibkan melakukan pembelajaran jarak jauh (PJJ) melalui media online. karena sasaran penelitian adalah siswa kelas VI maka peneliti melakukan penelitian melalui metode blanded learning yaitu menggabungkan metode daring dan metode luring karena dari 86 sampel yang peneliti dapatkan ada beberapa siswa yang tidak memungkinkan untuk melaksanakan metode daring.

Pada angket penggunaan gawai jumlah sampel yang melakukan pengisian secara daring sebanyak 74 siswa dan 12 siswa menjawab secara luring Sedangkan pada tes prestasi belajar matematika terdapat 78 siswa menjawab secara daring dan 8 siswa menjawab secara luring.Angket yang digunakan untuk mengetahui gambaran pengaruh penggunaan gawai terdapat 30 jumlah pernyataan masing-masing 15 jumlah pernyataan positif dan 15 butir pernyataan negatif. Sementara soal untuk tes prestasi belajar matematika terdiri dari 30 butir soal pilihan ganda

Pengolahan data hasil penilaian angket menggunakan aplikasi Microsoft Xl dan skala likert dengan Instrumen angket masing-masing berjumlah 30 pernyataan, dengan kriteria adalah sebagai berikut: (1)98 - 120: sangat tinggi. (2)76 - 97 : tinggi. (3)53 - 75 : cukup tinggi. (4)30 - 52: kurang tinggi. Hasil pengolahan data pada angket penggunaan gawai dapat disajikan seperti tabel dibawah ini.

Tabel 1. Kriteria penggunaan gawai

\begin{tabular}{|c|c|c|c|c|}
\hline NO & Skor Penilaian & Kategori & Frekuensi & Persentase (\%) \\
\hline 1 & $98-120$ & sangat tinggi & 43 & 50 \\
\hline 2 & $76-97$ & tinggi & 42 & 49 \\
\hline 3 & $53-75$ & cukup & 1 & 1 \\
\hline 4 & $30-52$ & kurang & 0 & 0 \\
\hline \multicolumn{7}{r}{ Total } & 86 & 100 \\
\hline
\end{tabular}

Sumber : data hasil penelitian 2021

Setelah mengamati perhitungan tabel diatas, data pada angket penggunaan gawai setelah dikonversi kedalam 4 kategori yaitu sangat tinggi,tinggi,cukup,dan kurang. Jumah siswa yang masuk pada kategori sangat tinggi sebanyak 43 orang dengan presentase $50 \%$, yang berkategori tinggi sebanyak 42 orang dengan nilai presentase adalah $49 \%$, sedangkan yang masuk pada kategori cukup sebanyak 1 orang dengan presentase $1 \%$ dan tidak terdapat siswa pada kategori kurang. Pada penggunaan gawai ada dua indikator yang disajikan yaitu indikator pemanfaatan gawai dan indikator fungsi gawai. Yang paling menonjol dari kedua indikator tersebut adalah indikator pemanfaatan gawai dimana terdapat 26 siswa (30\%) masuk pada kategori sangat tinggi,59 siswa (69\%) masuk pada kategori tinggi,dan 1 siswa (1\%) masuk pada kategori cukup.

Pada penggunaan gawai ada dua indikator yang disajikan yaitu indikator pemanfaatan gawai dan indikator fungsi gawai. Yang paling menonjol dari kedua indikator tersebut adalah indikator pemanfaatan gawai dimana terdapat 26 siswa (30\%) masuk pada kategori sangat tinggi,59 siswa (69\%) masuk pada kategori tinggi,dan 1 siswa (1\%) masuk pada kategori cukup

Hasil prestasi belajar matematika di peroleh dari nilai hasil tes belajar soal matematika kelas VI semester 1. Untuk mengetahui hasil tes prestasi belajar matematika digunakan daftar nilai kognitif dengan Kriteria Ketuntasan Minimal (KKM) 75. Dalam penentuan ketuntasan belajar individu hasil belajar setiap siswa.Dengan indikator keberhasilan, siswa dapat dikatakan 
telah menyelesaikan pembelajarannya (tuntas) jika memperoleh nilai sesuai standar Kriteria ketuntasan Minimum (KKM) 75, dapat dilihat pada tabel dibawah ini

Tabel 2. Kriteria prestasi belajar matematika

\begin{tabular}{|c|c|c|c|}
\hline No & Deskripsi data & Jumlah & Presentase Ketuntasan Individual (\%) \\
\hline 1 & Tuntas & 51 & 59 \\
\hline \multirow[t]{2}{*}{2} & Tidak tuntas & 35 & 41 \\
\hline & Jumlah & 86 & 100 \\
\hline
\end{tabular}

Sumber : data hasil penelitian 2021

Perhitungan tabel diatas berdasarkan kriteria ketuntasan minimal (KKM) diperoleh 51 siswa tuntas atau $59 \%$ dan 35 dinyatakan tidak tuntas atau $41 \%$ dari seluruh siswa

\section{Hasil Uji Analisis Data Statistik Inferensial}

\section{Uji Normalitas}

Uji normalitas dilakukan pada daftar hasil nilai kognitif penggunaan gawai. Hasil prestasi belajar diperoleh dari nilai tes matematika. Hasil pengolahan data tersebut untuk mengetahui apakah datanya normal atau tidak yang merupakan persyaratan untuk menentukan jenis data statistik apa yang harus digunakan dalam analisis selanjutnya. Sementara untuk pengujian Hipotesis adalah: $\mathrm{H}_{\mathrm{o}}=$ data berasal dari populasi berdistribusi normal, $\mathrm{H}_{1}=$ data berasal dari populasi tidak berdistribusi normal.

Sebelum dilakukan perhitungan uji normalitas ini terlebih dahulu dengan menggunakan bantuan dari perangkat lunak SPSS melalui uji Lilliefors (Kolmogorov-Smirnov) karena jumlah sampel lebih dari 50. Kriteria pengujian dengan taraf signifikansi 5\%. Taraf signifikan yaitu $(\mathrm{a}=0,05)$ jika nilai $\mathrm{P}$-value $($ sig $) \leq 0,05$ maka $\mathrm{H}_{\mathrm{o}}$ ditolak dan $\mathrm{H}_{1}$ diterima dan jika nilai $\mathrm{P}$-value (sig) $>0,05$ maka $\mathrm{H}_{\mathrm{o}}$ diterima dan $\mathrm{H} 1$ di tolak.

\section{Uji Linieritas}

Uji linieritas merupakan langkah untuk menentukan apakah dua variabel bebas mempunyai hubungan linier yang signifikan. Hasil yang didapatkan dari uji linier menentukan persamaan garis regresi variabel bebas (X) terhadap variabel terikat (Y). Uji linieritas menggunakan SPSS yaitu uji linieritas untuk linieritas kolom sig baris dengan melihat tabel anova pada bagian kolom sig baris linearity. Apabila signifakansi $<0,05$, dan nilai deviation from linearity signifikansi $>0,05$ dapat disimpulkan bahwa hubungannya linear.

Berdasarkan hasil output uji linearitas penggunaan gawai dengan menggunakan test for linearity dengan melihat tabel anova pada tabel tersebut terlihat bahwa nilai sig. deviation from linearity pada kolom signifikansi 0,383 karena nilai signifikansi lebih besar dari 0,05 dimana $0,383>0,05$ maka dapat dikatakan bahwa terdapat hubungan yang linear antara penggunaan gawai dan prestasi belajar.

\section{Uji Multikolienaritas}

Uji multikolienaritas dilaksanakan untuk mengetahui apakah ada atau tidak ada hubungan yang kuat antara variabel bebas.Kriteria yang digunakan adalah uji VIF dan koofisen korelasi antara variabel bebas. Jika nilai VIF mendekati 1 (satu) dan nilai toleransi juga mendekati 1 (satu) serta kurang dari 10 (sepuluh) maka dikatakan bahwa tidak terjadi masalah multikolinearitas.

Hasil uji multikolinieritas dapat dilihat diperoleh nilai VIF variabel penggunaan gawai $\left(\mathrm{X}_{1}\right)$ adalah $1,027<10$ dan collinearity tolerance $0,973>0,1$ berarti tidak terjadi multikolinieritas. 


\section{Uji Heteroskedastisitas}

Uji heteroskedesitas dilakukan untuk mengetahui adanya ketidaksamaan varian dari residual untuk semua pengamatan dari model regresi. Dalam penelitian ini untuk memeriksa pola residual terhadap estimasi maka digunakan metode grafik dengan cara melihat grafik scatterplot ada tidaknya pola tertentu pada grafik scaterrplot dimana sumbu Y adalah Y yang telah diprediksi dan sumbu $\mathrm{X}$ adalah residual.

Berdasarkan hasil olah data pada uji hetroskedisitas tidak terdapat pola yang jelas seperti titik menyebar di atas dan di bawah angka 0 pada sumbu Y maka dapat disimpulkan bahwa tidak terjadi heteroskedastisitas.

\section{Uji Hipotesis.}

Hipotesis merupakan jawaban sementara atas suatu masalah dalam penelitian. Untuk membuktikan kebenarannya perlu dilakukan pengujian secara empirik. Pada penelitian ini pengujian hipotesis secara empirik menggunakan teknik analisis regresi untuk memprediksi pengaruh antar satu variabel dengan variabel lain.

\section{Uji hipotesis 1 (uji parsial t)}

Tingkat signifikan yang digunakan pada penelitian ini adalah tingkat signifikan 5\%. Berarti jika sig t-hitung kurang dari 0,05 maka $\mathrm{H}_{0}$ ditolak dan $\mathrm{H}_{1}$ diterima, yang berarti variabel bebas berpengaruh pada variabel terikat. Sebaliknya jika sig t-hitung lebih besar dari 0,05 maka $\mathrm{H}_{0}$ diterima dan $\mathrm{H}_{1}$ ditolak, yang berarti variabel bebas tidak berpengaruh pada variabel terikat.

Uji hipotesis penggunaan gawai dengan menggunakan uji one sample $T$ test menunjukkan bahwa nilai signifikansi adalah 0.805 dimana 0,805 $>0,05$ yang berarti $\mathrm{H}_{0}$ diterima dan $\mathrm{H}_{1}$ ditolak. Sehingga dapat dikatakan bahwa penggunaan gawai tidak berpengaruh secara signifikan terhadap prestasi belajar matematika.

\section{Uji hipotesis 2 (uji simultan f)}

Uji peningkatan prestasi belajar matematika setelah dilakukan tes prestasi belajar menggunakan uji one sample T test uji hipotesis prestasi belajar matematika menunjukkan nilai signifikan 0,781 dimana 0,781 lebih besar dari 0,05. Hal ini menunjukkan bahwa $\mathrm{H}_{0}$ diterima dan $\mathrm{H}_{1}$ ditolak ini berarti penggunaan gawai dan kontrol diri secara simultan tidak terdapat pengaruh secara signifikan terhadap prestasi belajar matematika siswa.

\section{Uji Determinasi $\left(\mathbf{R}^{2}\right)$}

Uji koefisien determinasi dilakukan untuk mengetahui tingkat ketepatan yang paling baik dalam analisis regresi, menunjukkan angka koefisien korelasi (R) sebesar 0,077 berada pada rentang $(0,0-0,199)$ kategori sangat lemah. Hasil ini menunjukkan bahwa penggunaan gawai dan kontrol diri memiliki hubungan yang sangat lemah terhadap prestasi belajar matematika siswa kelas VI SD di kecamatan wara. Dari output pada lampiran 21 didapatkan nilai Adjusted $R$ Square (Koefisien determinasi) sebesar 0,18 yang artinya pengaruh variabel independen $(\mathrm{X})$ terhadap variabel dependen $(\mathrm{Y})$ sebesar $18 \%$.

\section{Diskusi}

Dalam penelitian ini terdapat dua indikator yang digunakan pada penggunaan gawai yaitu indikator pemanfaatan gawai dan fungsi gawai bagi siswa untuk mengukur nilai pengaruh penggunaan gawai terhadap prestasi belajar matematika siswa. Berdasarkan indikator-indikator tersebut maka dimunculkanlah beberapa pernyataan-pernyataan yang dijawab langsung oleh siswa baik secara daring (menggunakan google formulir) maupun luring ( pemberian angket 
secara langsung) berdasarkan kondisi yang mereka alami selama pembelajaran masa pandemi, masing-masing pernyataan yang ada adalah pada pemanfaatan gawai dan fungsi gawai.

Pada penelitian ini penggunaan gawai terhadap prestasi belajar matematika siswa tidak berpengaruh secara signifikan. Pengaruh penggunaan gawai terhadap hasil prestasi belajar matematika siswa yang rendah juga sejalan dengan penelitian yang ditemukan oleh Sobon et.al (2019) dan Wiryanto (2020) mengemukakan bahwa pengaruh penggunaan smartphone terhadap motivasi belajar siswa masuk dalam kategori rendah,artinya variabel penggunaan smartphone bukan faktor dominan dan utama untuk meningkatkan prestasi belajar siswa di tingkat SD.

Pertiwi (2018) menekankan bahwa penggunaan smartphone tidak berpengaruh pada prestasi belajar siswa, yang berarti siswa dapat memanfaatkan teknologi dengan baik. Jika siswa dapat menggunakan smartphone dengan baik, seperti menggunakan smartphone untuk mencari topik, maka smartphone memiliki dampak yang baik pada prestasi belajar tetapi sebaliknya jika siswa menggunakan smartphone hanya untuk bermain game dan menggunakan hal-hal yang tidak baik maka akan mempengaruhi prestasi belajar siswa tersebut. Sedangkan pada penelitan ini setelah melakukan observasi didapatkan aspek penggunaan gawai indikator yang paling menonjol adalah pemanfaatan gawai sendiri, Pemanfaatan gawai menjadi sangat tinggi karna disebabkan oleh beberapa faktor misalnya: (1) Siswa menggunakan gawai tanpa pengawasan dari orang tua, hal ini menjadikan sebahagian siswa menggunakan gawai hanya untuk mengakses permainan-permainan online. (2) Mereka hanya mengakses aplikasi media sosial yang tidak berhubungan dengan pembelajaran mereka. Faktor -faktor tersebut yang menjadi penyebab intesitas penggunaan gawai sangat tinggi tetapi tidak berpengaruh terhadap prestasi belajar matematika, selain faktor diatas ada beberapa siswa yang berpendapat bahwa penggunaan gawai dalam proses belajar daring tidak efektif karna mereka kurang memahami pembelajaran melalui media online, serta rasa jenuh yang mereka rasakan akibat pembelajaran daring menggunakan gawai yang berkepanjangan.

Pada penelitian ini prestasi belajar didapatkan dari hasil nilai tes yang dibagikan kepada siswa kelas VI SD di Kecamatan Wara Kota Palopo. Prestasi hasil belajar matematika siswa di anggap tuntas Hal ini menunjukkan bahwa gawai dapat berfungsi dengan baik pada proses belajar daring khususnya belajar matematika serta dapat menjadikan salah satu alternatif penunjang proses pembelajaran daring hal ini sejalan dengan penelitian yang dilakukan oleh Syifa et al (2019) yang mengemukakan bahwa hubungan antara kecenderungan bermain gawai Dalam hal ini motivasi dan prestasi belajar memilki dampak positif atau negatif dari kegiatan bermain gawai dan dapat meningkatkan bahkan menurunkan motivasi belajar siswa dan prestasi belajar siswa yang diperoleh di sekolah.

Pada penelitian ini berdasarkan hasil observasi pengolahan data bahwa tidak terdapat pengaruh yang signifikan antara penggunaan gawai dan kontrol diri terhadap prestasi belajar matematika siswa SD kelas VI yang berada di Kecamatan Wara Kota Palopo. Pengaruh yang tidak signifikan ini di pengaruhi oleh beberapa faktor yang dapat di amati oleh peneliti yang juga merupakan kendala pada saat melakukan penelitian seperti lokasi penelitian yang terdiri dari 12 Sekolah Dasar yang tersebar di Kecamatan Wara sehingga memunculkan berbagai pola pikir dan karakteristik yang berbeda tiap siswa dalam menjawab pernyataan-pernyataan dalam angket serta tes matematika yang diberikan.

Perbedaan penelitian ini dengan penelitian sebelumnya antara lain penelitian yang dilakukan oleh Istiqomah (2019) menyimpulkan bahwa lingkungan keluarga dan penggunaan smartphone sebagai media belajar berpengaruh secara signifikan terhadap prestasi belajar PAI siswa. Sementara penelitian ini dititik beratkan pada penggunaan gawai dan kontrol diri siswa. Alifzal (2020) menyimpulkan bahwa ada hubungan positif dan signifikan antara pola pemanfaatan smartphone dengan prestasi belajar 
Dari penjelasan diatas dapat ditarik kesimpulan bahwa penggunaan gawai dan kontrol diri tidak terdapat pengaruh secara signifikan terhadap prestasi belajar matematika siswa kelas VI SD di Kecamatan Wara pada masa pandemi Covid-19. Pada masa ini pemanfaatan gawai bagi siswa tidak di barengi dengan kontrol diri siswa terlihat bahwa siswa lebih banyak menggunakan gawai mereka untuk bermain game, mengunduh game, mendengarkan musik, dan lain-lain. Oleh karena itu, dapat disimpulkan bahwa jika pemanfaatan gawai tersebut tidak digunakan dalam pembelajaran akan mempengaruhi motivasi belajar siswa dan bahkan menurunkan prestasi belajar siswa. Selain beberapa perbedaan penelitian ini dari penelitian sebelumnya, penelitian ini juga memiliki beberapa kelebihan antara lain: pada penelitian ini penggunaan gawai dipilih karena sesuai dengan isu sekarang bahwa siswa melakukan pembelajaran jarak jauh dengan moda dalam jaringan dimana pembelajaran otomatis menggunakan gawai sebagai sarana yang sangat dibutuhkan dalam melakukan pembelajaran jarak jauh tersebut untuk memenuhi tujuan pembelajaran jarak jauh yaitu memastikan pemenuhan hak peserta didik untuk mendapatkan layanan pendidikan selama darurat covid-19. Pada masa ini ini guru perlu merancang pembelajaran aar lebih menarik,berkesan,dan bermakna bagi siswa yang berarti sejalan secara konteks dan konten dengan kehidupan siswa karena pada pembelajaran jarak jauh ini proses pembelajran tidak sepenuhnya dikendalikan oleh guru tetapi jua dibutuhkan peran serta orang tua di rumah

\section{Simpulan}

Berdasarkan hasil penelitian yang dilakukan dapat ditarik beberapa kesimpulan sebagai berikut : Gambaran penggunaan gawai pada SD penggunaan gawai terdapat 3 kategori yaitu sangat tinggi berada pada interval nilai 98 - 120 dengan persentase 3\%, kategori tinggi pada interval 76 - 97 dengan persentase 95 siswa dan kategori sedang 1\% dengan interval $53-75$. Gambaran prestasi belajar matematika pada SD berdasarkan Kriteria Ketuntasan Minimum (KKM) diperoleh 51 siswa tuntas atau 59\% dan 35 siswa lainnya atau $41 \%$ tidak tuntas. Pengunaan gawai tidak berpengaruh secara signifikan terhadap prestasi belajar matematika siswa SD pada masa pandemi Covid-19 dengan nilai signifikansi 0,085. Penggunaan gawai tidak berpengaruh secara signifikan terhadap prestasi belajar matematika pada siswa SD pada masa pandemi Covid-19 berdasarkan uji simultan (uji F) nilai signifikansi 0,781 dimana 0,781 $>0.05$, dan berdasarkan uji koofisien determinasi yang mendapatkan nilai R sebesar 0,77 berada pada rentan nilai $0,0-0,199$

\section{Konflik Kepentingan}

Penulis menyatakan tidak ada konflik kepentingan

\section{Referensi}

Afandi, M. A. (2020). Pengaruh Penggunaan Smartphone Terhadap Prestasi Belajar Siswa Kelas XI MIPA SMAN 10 Semarang. Jurnal Pendidikan, 8(1), 43-51.

Alifzal, F. (2020) Pengaruh Penggunaan Handphone Terhadap Prestasi Belajar Sejarah Siswa Kelas X IPS SMA PGRI 2 Kota Jambi. Jurnal Pengaruh Penggunaan Handphone Terhadap Prestasi Belajar Sejarah Siswa Kelas X Ips Sma Pgri 2 Kota Jambi. 
Hidayat, A. R., \& Junianto, E. (2017). Pengaruh gadget terhadap prestasi siswa smk yayasan islam tasikmalaya dengan metode tam. Jurnal Informatika, 4(2).

Istiqomah, W. (2019). Hubungan Intensitas Penggunaan Gadget Dan Motivasi Belajar Dengan Hasil Belajar IPS Kelas V SD Negeri Gugus Drupadi Kecamatan Gunungpati Semarang (Doctoral dissertation, Universitas Negeri Semarang).

Pertiwi. (2018). Gambaran Perilaku Penggunaan Gawai dan Kesehatan Mata pada Anak usia 10-12 Tahun. Jurnal Keperawatan Muhammadiyah.Vol.3.No.1.Hlm. 30.

Sobon, K., Mangundap, J. M., \& Walewangko, S. (2019). Pengaruh Penggunaan Smartphone Terhadap Motivasi Belajar Siswa Sekolah Dasar di Kecamatan Mapanget Kota Manado. Autentik: Jurnal Pengembangan Pendidikan Dasar, 3(2), 97-106.

Syifa, L., Setianingsih, E. S., \& Sulianto, J. (2019).Dampak Penggunaan Gadget terhadap Perkembangan Psikologi pada Anak Sekolah Dasar. Jurnal Ilmiah Sekolah Dasar, 3(4), 527-533.

Widiawati, I, Sugiman, H \& Edy.(2014). Pengaruh Penggunaan Gadget Terhadap Daya Kembang Anak. Jakarta: Universitas Budi Luhur.Diambil pada tanggal13April2019,darihttp://stmikglobal.ac.id/wpcontent/uploads/2014/05/

ARTIKELIIS.pdf Winarno, W. (2009). Panduan Penggunaan Gadget. Jakarta: Rineka Cipta. Zubaedi. (2011). Desain Pendidikan Karakter: Konsepsi dan Aplikasi dalam Dunia Pendidikan. Jakarta: Kencana.

Wiryanto, W. (2020).Proses Pembelajaran Matematika Di Sekolah Dasar Di Tengah Pandemi Covid-19. Jurnal Review Pendidikan Dasar: Jurnal Kajian Pendidikan dan Hasil Penelitian, 6(2), 125-132. 